Volume 10|Issue5

November 2019

\title{
Planning Around Reserves: Probing the Inclusion of First Nations in Saskatchewan's Watershed Planning Framework
}

Warrick Baijius

University of Saskatchewan, warrick.baijius@usask.ca

Robert J. Patrick

University of Saskatchewan, robert.patrick@usask.ca

Recommended Citation

Baijius W., \& Patrick, R. J.(2019). Planning around reserves: Probing the inclusion of First Nations in Saskatchewan's watershed planning framework. The International Indigenous Policy Journal, 10(5). doi: https://10.18584/iipj.2019.10.5.8502 


\title{
Planning Around Reserves: Probing the Inclusion of First Nations in Saskatchewan's Watershed Planning Framework
}

\begin{abstract}
Watershed-based planning in Saskatchewan began in earnest after 2006 under the auspices of the Saskatchewan Watershed Authority. Within a decade, a dozen watershed plans were produced following a planning framework that included technical and watershed resident committees. First Nation communities, or "reserves," exist within these watershed areas. This article probes the inclusion of First Nations in those plans. Using document analysis and keyword search, our analysis explores any spatial relationship that may exist between First Nation inclusion and the amount of reserve land in a watershed. The results of this research show that First Nation inclusion is limited in watershed planning in Saskatchewan. We see opportunity for more effective watershed planning through greater collaboration with First Nations.
\end{abstract}

\author{
Keywords \\ watershed planning, First Nations, Indigenous, Saskatchewan, Canada
}

Acknowledgments

Funding for this research was provided from the Canadian Pacific Railway Partnership Program in Aboriginal

Development

\section{Creative Commons License}

(c) (1) $\Theta \Theta$

This work is licensed under a Creative Commons Attribution-Noncommercial-No Derivative Works 4.0License. 


\section{Planning Around Reserves: Probing the Inclusion of First Nations in Saskatchewan's Watershed Planning Framework}

The colonization of Indigenous Peoples in what is now Canada became institutionalized through the federal government's Indian Act of 1876. The Indian Act (1985) set out to control all aspects of Indigenous People's lives including, but not limited to, land occupation, resource access, education, cultural traditions and practices, religion, individual mobility, language, and the right to vote (see also Arsenault, Diver, McGregor, Witham, \& Bourassa, 2018; Truth \& Reconciliation Commission of Canada, 2015). The federally controlled system of Indian reserves, a creation of the Indian Act, served to concentrate and constrain Indigenous people on "federal lands" with the purpose of severing Indigenous Peoples' long-held relationship with the land-a relationship that included resource sharing, seasonal habitation and migration, as well as communal clan, or family, structures (Arsenault et al., 2018). The broad powers of the Indian Act impacted the health of Indigenous Peoples in multiple ways, including through restricted movement of Indigenous Peoples outside of reserves, prohibition on cultural practices, and the imposition of European land management and planning practices. Collectively, these impacts resulted in what has been termed today as cultural genocide (Wolfe, 2006).

One of the many outcomes of colonization was the creation of dependency on the state to provide for all aspects of Indigenous life - from land use planning to housing and community infrastructure (McGregor, 2014; Patrick, Machial, Quinney, \& Quinney, 2017). The state system of Indian reserves not only removed Indigenous people from the landscape but also excluded them from state-based institutions of decision-making, such as community development and planning. Colonialism and settlement also imposed an individualist notion of property and ownership on the landscape (Krueckeberg, 1995), dividing it up into discrete parcels from which people and activities could be excluded. This contrasts with pre-settlement Indigenous relations with the land, in which Indigenous people belonged to and emerged from an ecological context, practising an ethic of sharing with humans and other-than-human beings (Belanger, 2010). With colonialism, not only were Indigenous Peoples physically excluded from participating in resource management and other decision-making venues, but so too were their philosophies, knowledge, and laws excluded from defining "what is to be managed" (Borrows, 2002; Howitt \& Suchet-Pearson, 2006; Natcher, 2001).

\section{Participation in Resource Management and Planning}

Evaluation of participation in resource management, planning, and governance can address process, final outcomes, and intermediary outcomes (Carr, Blöschl, \& Loucks, 2012), but the time scale of participation in planning and management may not be easily reconciled with the length of time it takes for the environment to respond to various interventions. Similar issues of attribution are recognized when assessing Indigenous inclusion in forestry management in Canada (Wyatt, Merrill, \& Natcher, 2011). Regardless of evaluation and attribution, it is evident that having meaningful and efficient engagement in planning and management, especially when Aboriginal and treaty rights are involved, will require early and on-going participation of Indigenous Peoples (Noble, 2016; Udofia, Noble, \& Poelzer, 2016).

Assessments of plans and processes for Indigenous engagement are ongoing in the Canadian forestry sector (Fortier, Wyatt, Natcher, Smith, \& Hébert, 2013; Wyatt et al., 2011), but there is a notable lack of 
similar approaches being used for the assessment of watershed plans. In addition to that mentioned above, prior research into the participation and inclusion of Indigenous Peoples in Canadian resource management consistently identifies social factors such as financial and capacity constraints (Lebel \& Reed, 2010; Morrison, Bradford, \& Bharadwaj, 2015; Rizvi, Adamowski, \& Patrick, 2013; Walters, Spence, Kuikman, \& Singh, 2012). It also identifies fundamental political or structural issues that lead to institutionalized inequity and injustice (Basdeo \& Bharadwaj, 2013), and the differing perspectives of those involved in planning and management (Ferreyra, de Loë, \& Kreutzwiser, 2008; Montgomery, Xu, Bjornlund, \& Edwards, 2016; Morton, Gunton, \& Day, 2012). Other research has examined the impacts of land management and property classification on drinking water outcomes for on-reserve communities (Baijius \& Patrick, 2019).

Often, researchers suggest that inclusion of Indigenous Peoples in water governance is more important than in water management (Bradford, Ovsenek, \& Bharadwaj, 2017; Castleden, Hart, Cunsolo, Harper, \& Martin, 2017), eschewing their potential role as citizen stakeholders within provincial processes (Porten, Loë, \& Plummer, 2015). Although participation in state-based management and planning processes has some barriers and opportunities, as recognized in the literature cited above, it may be that a strategy of pragmatism that includes consensus, conflict, social protest, and participation is more effective than other approaches in isolation (Borrows, 2005; Hanna, Langdon, \& Vanclay, 2016; Maclean, Robinson, \& Natcher, 2015; Wanvik \& Caine, 2017). While participation in watershed planning by Indigenous Peoples can be part of a broader strategy, it may also be a reflection of shifting social norms regarding the recognition of the rights and responsibilities of Indigenous Peoples to the land and water, and to inclusion in governing how we relate to land and water (Clogg, Askew, Kung, \& Smith, 2016).

The purpose of this article is to examine the extent to which contemporary provincial watershed-scale planning processes in Saskatchewan have engaged, and been inclusive of, Indigenous Peoples. We use the content of watershed plans as evidence of Indigenous participation. To conduct this study, we completed a detailed analysis of existing watershed plans, tallied evidence of Indigenous presence, and explored the thematic context of keywords within the plan document using manifest and latent content analysis. ${ }^{1}$ Themes are identified inductively to provide insight into the issues, concerns, and interests recognized by the planning process that (potentially) result from Indigenous engagement. As well, we explore any correlation that may exist between the content of watershed plans (keywords and thematic diversity) and the number and size of First Nation reserves within the watershed.

\section{Watershed Planning in Saskatchewan}

In 2002, the provincial government created the Saskatchewan Watershed Authority with the goal of managing and protecting water quantity and source water quality in Saskatchewan. To achieve this goal, a planning model was created, and responsibilities and roles were defined for three committees: watershed advisory committee, technical committee, and planning team (Saskatchewan Watershed

\footnotetext{
${ }^{1}$ In some places throughout this article, we use the term Indigenous inclusively to refer to individuals and groups who selfidentify as Indigenous. We also use the terms Aboriginal, First Nations, or Métis to refer to specific groups of Indigenous Peoples and communities as a legal entities created through the Constitution Acts (Government of Canada, 1982).
} 
Authority, 2003). Under this model, a combination of 11 source water protection plans and watershed plans were produced between 2006 and 2014, all in the southern half of the province. In 2012, the Saskatchewan Watershed Authority was renamed the Water Security Agency and it released the 25 Year Saskatchewan Water Security Plan-a document enabling both source water protection plans as well as comprehensive (water) plans (Water Security Agency, 2012).

In Saskatchewan, watershed planning does not occur with the same frequency as, for example, forestry planning, nor is the same degree of engagement legislated. The lack of multiple iterations of watershed planning in Saskatchewan makes it difficult to assess change in Indigenous engagement within specific watersheds over time. However, it is possible to gain insight into how inclusion has changed over time and across space by way of manifest content analysis of plan documents (McLeod et al., 2015).

The roles of space and place are significant in watershed planning and, by association, so is the notion of property, including tenure, zoning, and land use (Blomley, 2016). Water governance in the Canadian Prairies tends to privilege participation by way of property, especially in a rural context (Cuvelier \& Greenfield, 2017; Stewart \& Bennett, 2017). Citizens of rural municipalities, often farmers or resource workers, are represented by their local elected officials, who advocate for the interests of their electorate and are paid by their taxes. These representatives, as well as those of industry associations who benefit from specific types of public and private land uses, are dominant voices for the "propertied" (Hurlbert \& Andrews, 2018; Krueckeberg, 1995). The articulation of concerns about on-reserve water issues becomes subject to federal action, bringing additional complexity into the ways in which First Nations are included in water management and planning.

The Constitution Act provides for the division of powers between the two recognized levels of government in Canada, provincial and federal (Government of Canada, 1982; see also Irvine, 2002). "Lands reserved for the Indians" (Constitution Act, 1867, s. 91(24)) as specified in the Indian Act (1985) are considered federal, and thus outside provincial jurisdiction. At the same time, jurisdiction over water is within the power of the individual provinces, except for water within federal jurisdiction, including those "lands reserved for the Indians," or reserve lands (Bartlett, 1988). By implication, these lands and the watershed-based interests of those who live on "reserve" lands are not considered within the domain of provincial watershed planning. This jurisdictional divide potentially excludes First Nations from provincial planning practices due to the partitioning of watershed planning according to political boundaries and property lines (Patrick et al., 2017).

With changing social norms (political recognition of difference, Indigenous rights, innovations in epistemology and methodology, participatory governance) come increased expectations and desires to include Indigenous Peoples in watershed planning (McGregor, 2014; Patrick, 2014). However, without a strong structure of legislation and policy, as well as sufficient funding, the ability of planning to meaningfully engage with Indigenous Peoples on a nation-to-nation basis is limited (Phare, 2009; Simms, Harris, Joe, \& Bakker, 2016).

Considering watershed planning as a negotiation of interests amongst stakeholders in governance, we can expect to see representation of propertied interests (landowners, including private, public, and civil society environmental non-governmental organizations [ENGOs] and corporations) in watershed 
planning processes. Arguably, First Nations are "represented" by the federal government, but this does not provide Indigenous people a direct voice in matters of resource governance (Cairns, 2000).

\section{Methods}

In order to examine the extent to which the contemporary provincial watershed-scale planning processes in Saskatchewan has engaged with, and been inclusive of, Indigenous Peoples, we reviewed published Government of Saskatchewan watershed plans for Indigenous content. We employ manifest content analysis, tabulating the occurrence of keywords and identifying the context in which the keywords are used. The findings reveal a wide variation in the number of keywords present in the plans as well as the context in which they are used. The mere presence of specific keywords, such as First Nation or Indigenous, may not signify any form of meaningful engagement. However, through manifest content analysis, the context in which these keywords are present may provide greater insight into the extent of Indigenous engagement and inclusion in provincial watershed planning.

In seeking an explanation for this variation between the watershed plans, we combine the results from the manifest content analysis (counts, themes, and diversity) with a geospatial analysis. Specifically, we look for a relationship between the two content variables and four spatial variables: watershed extent; reserve land extent, including First Nation reserves and Treaty Land Entitlement (TLE) parcels; proportion or the relative percentage of reserve land in a watershed; and the number of First Nations with land in that watershed.

\section{Document Review and Content Analysis}

Following McLeod et al. (2015), Plummer, Grosbois, de Loë, and Velaniškis,(2011), and Wyatt et al. (2011), we conducted a combination of manifest and latent content analysis. Manifest content analysis involves a keyword search to identify indicator terms (McLeod et al., 2015) that may then be numerically tabulated into a frequency count. This level of document analysis provides one aspect of Indigenous inclusion, but it is a very shallow accounting, as keywords may be counted multiple times in a plan document without any record of context. We extend our analysis beyond keyword counts to include the context in which the keywords are used: This is the latent phase of the analysis.

Plummer et al. (2011) assessed the integration of land use and watershed planning by analyzing the number of references to integration in policies, plans, and reports, and the context in which those references occur. Where they looked for the degree of explicitness for integration statements"focus[ing] specifically on measuring the presence and extent of policy statements as opposed to gauging the effectiveness" (p. 4) - we look for diversity in the forms and types of engagement documented in the watershed plans.

In McLeod et al.'s (2015) analysis of the intersection between Ontario's "land use and resource management policies" (p. 1) and First Nations, the authors similarly included a wide range of documents, including legislation, regulations, and policy statements, as well as plans and associated texts. Their latent phase of the analysis examines the context of the keywords, looking specifically for mention of rights and specific Indigenous-state relations (consultation, duty to consult, accommodation, 
consent). Documents were then ranked according to evidence within the text of direct recognition, acknowledgement of rights (treaty and Aboriginal), and honouring the past in different ways.

We similarly seek to understand the differences between the frequency and use of keywords in the plan documents, but choose to develop and refine our types or forms of inclusion from the data (the context in which the keywords are found), rather than establishing all categories beforehand. This approach allows us to remain analytically open to the presence of different forms or types of inclusion and for diversity in those forms or types of inclusion between the plan documents.

Our review emphasizes text content rather than text coverage: We identify forms of inclusion within the plan, rather than calculate the page space allocated to First Nations or Métis issues and concerns. To do this, we use a computer-based qualitative data analysis package to analyse the content of the plan documents. First, we conducted a manifest analysis by a keyword search, identifying all sections of the documents where those keywords were found. These results were followed by latent analysis, where thematic codes were applied to larger blocks of text according to the way in which the keyword was incorporated into the text. For example, "First Nation" might have been mentioned in the context of rights or participation on a committee. Sub-codes were also developed to provide richer detail of nuances in the evidence of participation, inclusion, and voice within plan documents. The caseinsensitive text search was conducted with characters appropriate for the software search engine to identify variations and, for some terms, to exclude partial matches. For example, this string was used in order to be inclusive of Indigenous cultural groups that may be present or discussed in the context of resource management in Saskatchewan:

"first nation?” OR “indig*” OR “aborig*” OR “m?tis” OR “cree” OR “dene” OR “dakota” OR "nation"

\section{Geospatial Analysis}

To provide further context for the analysis, we identified the number of registered First Nations with reserve land and the area of reserve land in watersheds with plans. Using the lens of land use and property (Blomley, 2016; Krueckeberg, 1995; Valverde, 2005) to interpret the plan documents, we sought to identify potential factors in the distribution of Indigenous keywords within and across plans.

The proportion of reserve land in a watershed provides another way to analyze First Nations and Métis inclusion in the plan documents. A tenet of democratic participation in contemporary planning is that those who are impacted by planning should be included in it (Hodge, Hall, \& Robinson, 2016). We might expect that, with more land in a watershed, the potential for impacts from actions related to watershed planning increases. That is, people with more land are more likely to be affected by the decisions taken in the planning process. Assuming that First Nations are representing themselves in the process and speaking to issues that affect their reserve lands, we sought to identify any relationship between the spatial extent of First Nation land tenure (reserve and TLE) in a watershed and the frequency and type of Indigenous keywords within the plan document. 


\section{Materials \& Methods}

Vector data from the provincial government were used to count and calculate the extent of reserve parcels $^{2}$ in each watershed ${ }^{3}$ (Information Services Corporation of Saskatchewan, 2015; Saskatchewan Watershed Authority, 2013). Some parcels are jointly held by multiple First Nations; this dataset does not fully disaggregate title holders of these parcels, making it difficult to identify the actual number of First Nations with a stake in land use planning and management. We note this in the appropriate tables by counting the minimum number of First Nations with land in the watershed, based on the total number of individual First Nations with one or more reserve parcels in those watersheds.

The number of First Nations with land in a watershed provides us with a benchmark of the minimum number of First Nations who might have an interest in watershed planning. The actual number who do participate or have an interest may vary - community capacity and resources to participate, perceived impact, and perceived efficacy of participation can be reasons for opting out (Nadasdy, 2004). Conversely, Indigenous communities who do not have reserve land in the watershed may still lay claim to traditional territory and use in the watershed. Ultimately, reserve land must not be the sole factor used by planners to justify the inclusion of Indigenous Peoples, but it does provide a way to identify possible relationships between reserve land and representation in plan documents and planning processes. Our analysis proceeds without knowledge of traditional land use and occupancy in Saskatchewan, as these data are often still stored in land-based knowledge and oral history and thus not available to us for analysis.

As a preliminary study on a small dataset, the purpose of the analysis is to roughly characterize the relationships between the four spatial attributes of each watershed (total extent of watershed, total extent of reserved land, proportion of reserved land, number of First Nations with land), and plan content (keyword occurrences and thematic diversity). To do so, we look for linear correlation $(r)$ between pairs of variables. ${ }^{4}$ For some relationships, we further calculated the coefficient of determination $\left(r^{2}\right)$, a percentage value that describes the significance of the independent variable in explaining the variation in the dependent variable (Samuel \& Okey, 2015).

Using this approach, we can better understand the relationships between contents of plans (keyword occurrences and themes) and the spatial context in which they are produced (extent and proportion, number of First Nations with land). These calculated values tell us how linear a relationship is between two variables and the relative influence of the independent variable on the dependent one. It does not explain causality, nor any non-linear relationships that may exist.

\footnotetext{
${ }^{2}$ Reserve parcels are "polygon entities that depict the administrative boundaries (extent) of lands where the title has been vested in specific Aboriginal Groups of Canada or lands which were set aside for their exclusive benefit" (Information Services Corporation of Saskatchewan, 2015, metadata).

${ }^{3}$ Watershed polygons are derived from a geographic information system (GIS) dataset of gross and effective drainage areas (Agriculture and Agri-Foods Canada, 2013).

${ }^{4}$ The correlation coefficient is "[a] measure of the strength of linear association between two variables. Correlation will always fall between -1.0 and $+1.0 \ldots$. A zero correlation indicates that there is no relationship between the variables ... If the correlation is positive, we have a positive relationship. If it is negative, the relationship is negative ... [and the] strength of the relationship ... could be strong [ $r>0.8]$, moderate or weak $[0.5>r]$ ” (Samuel \& Okey, 2015, pp. 23-24).
} 


\section{Results}

\section{Document Review and Content Analysis}

Latent analysis of the text search results was used to develop themes that represent specific aspects of Indigenous inclusion in the plan documents. Seven major themes were identified, with the Indigenous Committee Membership theme providing insight into the distribution of participation between First Nations and Indigenous organizations as evident in the plan document. Below, tabular counts of the plans and content codes are followed by descriptions of the themes.

Table 1 shows the themes, the number of plans in which they appear, and the number of times they were found across all documents. Keyword occurrences ranged from 0 to 39, with an average of 12 per plan. Note that total keyword occurrences do not equal total theme instances. In some plans, keywords appeared in close proximity and in the same context, that is, multiple Indigenous keywords used in a paragraph defining First Nation. These individual instances were grouped together into a text "block," with the text block assigned to a single thematic instance.

Table 2 lists the plan documents, counts of the total number of keyword occurrences, number of occurrences within each theme by plan and in total, and a calculation of the theme diversity. ${ }^{5}$ Of the 11 completed watershed plans, all but one included an Indigenous keyword. Three plans appear as outliers (North Saskatchewan River, Upper Souris, Carrot River) and account for the majority of keyword counts in the data set (95/133 or 71\%). Of the six themes, Indigenous Committee Membership and Plan Implementation were by far the most common across all plans.

Table 3 provides detail on Indigenous inclusion with respect to committee membership. The first two columns show the watershed name and year the plan was completed. The next three columns list the number of times a keyword appeared in the context of committee membership- (Column 3) generally, with a statement of participation lacking names of individuals and their affiliation; or specifically, (Column 4) with the mention of an individual and their affiliation with a First Nation or (Column 5) Indigenous organization. In some plans, First Nations had more than one representative listed; the final column (Column 6) shows the total number of First Nations specifically and explicitly included in the plan.

\section{Theme 1: Indigenous Committee Membership}

Indigenous voice is linked to participation. Planning committee membership determines who gets to participate - and thereby represent - Indigenous issues, interests, and rights within the watershed (Cairns, 2000). Where plan documents indicate Indigenous participation in the planning process by way of membership on a committee, the text was assigned to the Indigenous Committee Membership theme. This theme was further differentiated in order to identify the number of Indigenous participants, as well as their affiliation.

\footnotetext{
${ }^{5}$ Theme diversity is calculated by taking the total number of themes and subtracting from that the number of themes in a plan that have keywords.
} 
Within the plan documents, Indigenous participation on watershed planning committees (often technical and steering committees) was indicated in two ways: generally, with a statement such as " $[\mathrm{t}] \mathrm{he}$ Committees' broad membership included representatives from urban and Rural Municipalities, industry, conservation organizations, Agri-Environmental Group Plan (AEGP) committee, and First Nations" (Carrot River Valley Watershed Association, 2012, p. 3) or, specifically, by way of listing an individual's name and affiliation in a committee's membership.

In total, five plans had general statements of inclusion, and seven plans had details about specific membership. Of those seven with specific details, six included First Nations and three included organizations. Sub-themes of the Indigenous Committee Membership theme and their counts, by watershed plan, are listed in Table 3. Both general and specific, as well as Nation and organization, appeared in various combinations across plan documents: Three plans included both a general statement of inclusion and a specific list of committee members where First Nations had one or more representative(s); three plans had specific membership but no general statement; one plan had a general statement with an organizational representative; and one plan had a general statement but no specifics about representation.

Table 1. List of Themes and Subthemes with Counts of Plans and Occurrences

\begin{tabular}{|c|c|c|}
\hline Thematic Codes & $\begin{array}{c}\# \text { of plans } \\
(n=11)\end{array}$ & Occurrences \\
\hline Indigenous committee membership & 8 & 37 \\
\hline General & 5 & 6 \\
\hline Specific & 7 & 31 \\
\hline First Nation & 6 & 27 \\
\hline Indigenous organization & 3 & 4 \\
\hline Definition & 5 & 7 \\
\hline History & 1 & 4 \\
\hline Plan implementation & 4 & 21 \\
\hline Rights & 4 & 5 \\
\hline Spatial location, map & 3 & 12 \\
\hline \multirow[t]{2}{*}{ Values, interests } & 4 & 9 \\
\hline & Total & 95 \\
\hline
\end{tabular}

Note. Subthemes are indented, with their occurrences aggregated in the parent theme (i.e., Specific tallies the number of plans and occurrences for both First Nation and Indigenous organization; Indigenous committee membership tallies the number of plans and occurrences for both General and Specific). The Total coding count (bottom row) tallies only parent themes. 

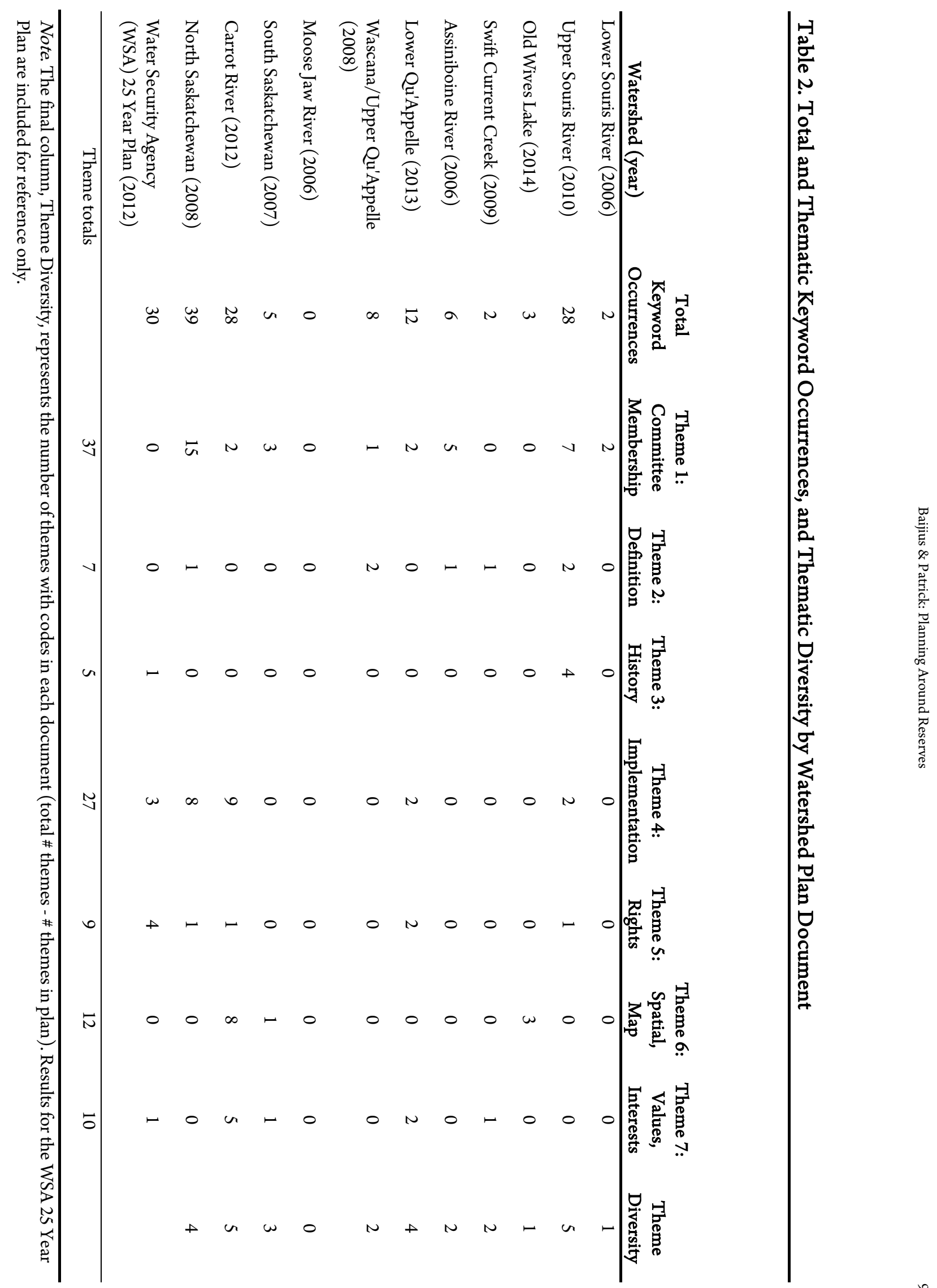

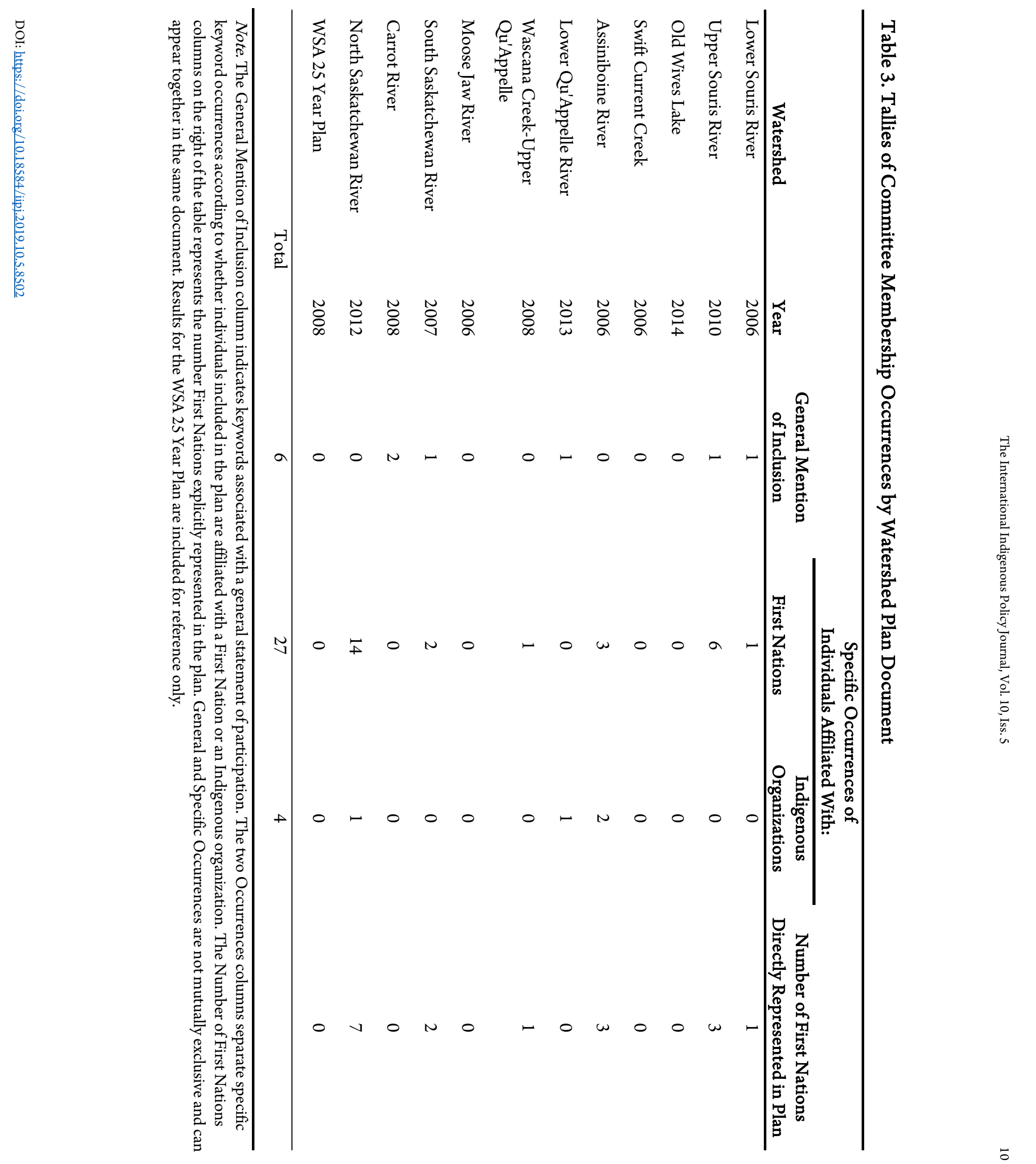


\section{Theme 2: Definition}

Where the search keywords (Indigenous, Aboriginal, First Nation) were defined somewhere in the plan, the text was coded as a Definition theme. Definitions were largely consistent across plans that included a definition, though inconsistent in their inclusion. Overall, 5 of the 11 plans included a total of 7 instances where terms specific to Indigenous Peoples were defined: five First Nation, one Métis, and one Aboriginal. Further, 2 of the 5 plans included multiple definitions: one with First Nation and Métis (Upper Souris), and the other with First Nation and Aboriginal (Wascana-Upper Qu'Appelle). First Nation was defined as "an Indian band or an Indian community functioning as a band but not having official band status, not including Inuit or Métis peoples” (North Saskatchewan River Basin Council, 2008, p. 78). Métis was defined as "a person who self-identifies as Métis, is of historic Métis Nation ancestry, is distinct from other Aboriginal peoples and is accepted by the Métis Nation” (Upper Souris Watershed Association, 2010, p. 38). Aboriginal "as identified in s. 35, Constitution Act, 1983, includes the Indian, Inuit and Métis peoples of Canada” (Upper Qu'Appelle River \& Wascana Creek Watersheds Advisory Committees, 2008, p. 59).

\section{Theme 3: History}

Where the plan text referenced Indigenous Peoples in relation to the history of human habitation and settlement of the watershed, the History theme was applied. Only one plan (Upper Souris) included reference to historical Indigenous occupation, with four occurrences in the document. The history of Indigenous relationships with the land and with settlers that are included in this document narrate the treaty signing process, European cultural influences, and the history of Métis in the region.

\section{Theme 4: Plan Implementation}

Where Indigenous interests were associated with a plan objective, or Indigenous communities and organizations identified as partners or participants in the implementation of plan actions, this theme was applied. Within this theme are general descriptions of inclusion in implementation activities, as well as specific actions, objectives, and partnerships. An example of general text from the Lower Qu'Appelle document states:

The activities described within the Watershed Plan will be implemented in a manner that respects local values and the input, the mandates and the responsibilities of the various levels of government (federal, provincial, municipal and First Nations). All parties will supply resources and collaborative efforts to implement the plan. (Lower Qu'Appelle Watershed Stewards, 2013, p. 33)

From the Carrot River plan, the intent is to "[d] evelop a stronger relationship between the Carrot River Valley Watershed Association, Red Earth Cree Nation, Aboriginal Affairs and Northern Development Canada and Watershed Authority to investigate flood protection measures" (Carrot Valley Watershed Association, 2012, p. 17). Overall, 4 of the 11 plans included Indigenous communities in plan implementation, either generally or in relation to specific actions, with a total of 24 instances. 


\section{Theme 5: Rights}

Indigenous rights, including sui generis (inherent rights), human, treaty, and Aboriginal rights, may be impacted by actions associated with the implementation of a watershed plan, such as through water allocation, land use planning, or environmental and hydrological management. Where a document recognizes this, or discusses the historical context of Indigenous rights, the text was coded under the Rights theme.

In the plans, rights were typically discussed in a discursive manner, using general language such as pointing out differing perspectives on these rights by "understanding of the range of interpretations of Treaty and Aboriginal rights in First Nations, Métis and non-First Nations communities” (Lower Qu'Appelle, 2013, p. 36). In contrast to the lack of discussion in any of the plans, the Saskatchewan WSA 25 Year Plan includes language about consultation:

Where water management decisions may have an adverse impact on the exercise of treaty and aboriginal rights and pursuit of traditional uses, consult with First Nations and Métis in accordance with the First Nations and Métis Consultation Policy Framework and the legal duty to consult (ongoing). (WSA 25 Year Plan, p. 37)

Indirect recognition of rights also exists, such as this statement in relation to forestry: "Commercial harvesting can also occur on private and Indian Reserve lands, which are not subject to the Saskatchewan Ministry of Environment's licensing requirements" (North Saskatchewan River Basin Council, 2008, pp. 63-64). Three documents mentioned Indigenous rights a total of four times, always in terms of treaty and Aboriginal rights, and never in terms of international law or human rights.

\section{Theme 6: Spatial Location, Map}

Where the keywords were in text describing the spatial location of a First Nation, Métis settlement, or reserve land, or where those Nations or lands were depicted on a map, the text was assigned to this theme. Three plans referenced some spatial aspect of Indigenous lands or communities, such as describing a general location, explaining a map feature, or identifying Indigenous communities within the watershed. A total of 12 instances of this theme were identified.

\section{Theme 7: Values, Interests}

Values and interests include text that explicitly mentions Indigenous values or interests in relation to watershed management. Nine instances were identified, with one additional in the WSA 25 Year Plan relating to traditional land and resource use. Some of the values and interests are general statements of inclusion (multiple), or more specific interests such as flood mitigation (Carrot River), wastewater (Lower Qu'Appelle), and drinking water (South Saskatchewan River).

\section{Geospatial Results}

With our focus on the content of watershed plans, we include in the spatial analysis only those watersheds in Saskatchewan with a plan, as indicated in Figure 1. The year of plan completion, the total 
watershed area $\left(\mathrm{km}^{2}\right)$, total reserve land $\left(\mathrm{km}^{2}\right)$, the proportion of watershed as reserved land, and the number of First Nations with reserve land in the watershed for each of those plans are presented in Table 4. Of the 12 watersheds included, 2 are combined under a single management plan (Wascana Creek and Upper Qu'Appelle River), resulting in 11 watershed plans. Plan completion years range from 2006 to 2014, with most plans completed prior to 2010. Watershed extents vary significantly, as do extent of reserve land within each watershed. The locations and distribution of reserve parcels, and both planned and unplanned watersheds, are depicted in Figure 1.

The plan for Old Wives Lake, despite three Nations having land in the watershed, shows no evidence of Indigenous involvement. The Lower Qu'Appelle watershed plan, where at least 16 Nations have land in the watershed, did not mention any First Nations but had did have one Indigenous organization listed as a participant.

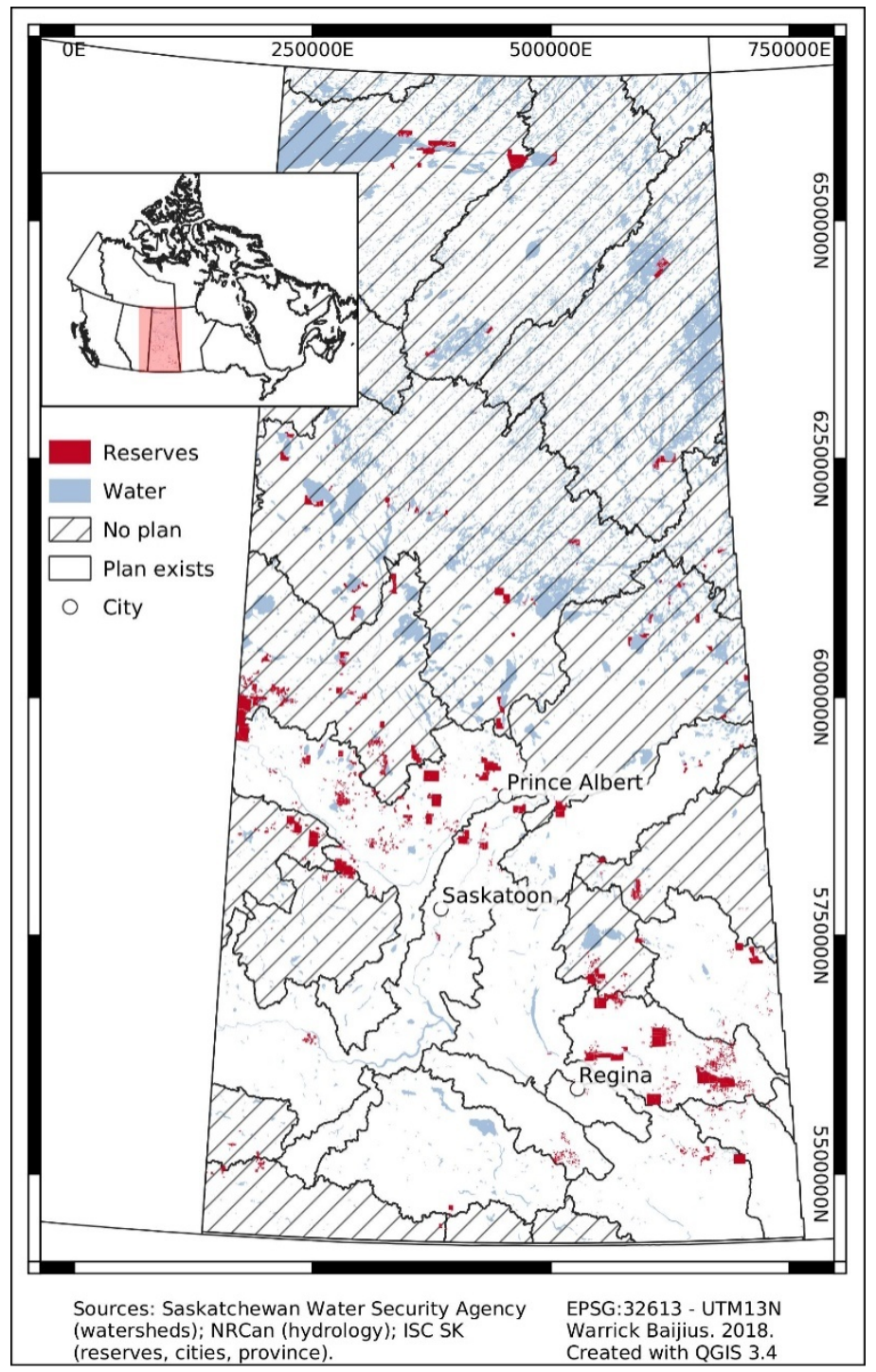

Figure 1. Distribution of catchments (planned and unplanned) and reserves in Saskatchewan. 
Table 4. Extent of Watershed, Reserve Land, and Number of First Nations with Land by Watershed with a Plan Document

\begin{tabular}{lccccc}
\hline \multicolumn{1}{c}{ Watershed } & Year & $\begin{array}{c}\text { Watershed area } \\
(\mathbf{s q . ~ k m})\end{array}$ & $\begin{array}{c}\text { Reserve land } \\
(\mathbf{s q . ~ k m})\end{array}$ & $\begin{array}{c}\text { \% Reserve } \\
\text { land }\end{array}$ & $\begin{array}{c}\text { \# of First } \\
\text { Nations } \\
\text { with land }\end{array}$ \\
\hline Lower Souris River & 2006 & $9,165.11$ & 706.32 & $7.7 \%$ & 4 \\
Upper Souris River & 2010 & $20,136.86$ & 823.83 & $4.1 \%$ & 6 \\
Old Wives Lake & 2014 & $24,477.93$ & 271.28 & $1.1 \%$ & 3 \\
Swift Current Creek & 2006 & $3,932.90$ & 118.48 & $3.0 \%$ & 1 \\
Assiniboine River & 2006 & $17,694.91$ & 765.97 & $4.3 \%$ & 8 \\
Lower Qu'Appelle River & 2013 & $17,147.41$ & $2,266.59$ & $13.2 \%$ & min. 16 \\
Wascana Creek $\left(^{*}\right)$ & 2008 & $3,865.43$ & 518.55 & $13.4 \%$ & 6 \\
Moose Jaw River & 2006 & $9,424.52$ & 297.18 & $3.2 \%$ & 1 \\
South Saskatchewan River & 2007 & $39,397.15$ & 672.5 & $1.7 \%$ & 9 \\
Upper Qu'Appelle River $\left(^{*}\right)$ & 2008 & $19,577.10$ & 727.79 & $3.7 \%$ & min. 3 \\
Carrot River & 2012 & $17,522.39$ & 264.86 & $1.5 \%$ & 6 \\
North Saskatchewan River & 2008 & $37,700.08$ & $2,564.15$ & $6.8 \%$ & 22 \\
\hline & Total & $\mathbf{2 2 0 , 0 4 1 . 7 9}$ & $\mathbf{9 , 4 7 8 . 9 5}$ & $4.3 \%$ & \\
\hline
\end{tabular}

Note. Watersheds with an asterisk $\left(^{*}\right)$ are combined in a single plan; 11 plans cover 12 watersheds.

Coefficient values for all watersheds are shown in Table 5, while Table 6 excludes previously identified outliers (North Saskatchewan, Upper Souris, and Carrot River). These tables show the correlation coefficient of pairs of variables discussed above. We focus on variable pairs showing moderate and stronger relationships $(r>0.50)$ and calculate the $r^{2}$ value for those pairs to better understand the relationship between the variables (to what degree the change in one variable leads to change in the other). Results in the tables are shaded to indicate three groups: Content (between keyword occurrences and theme diversity); Spatial (between the four spatial variables); and Combined (between content and spatial variables).

\section{Content}

The single coefficient in this group is for the relationship between keyword occurrences and theme diversity. It is a strong relationship and in a positive direction with $\left(r=0.83, r^{2}=0.68\right)$ and without $\left(r=0.85, r^{2}=0.72\right)$ outliers that suggests the number of keyword occurrences is associated with an increase in thematic diversity within plans in a linear way. The closeness of their values indicates that outlier plans do not significantly alter the relationship between keyword occurrences and theme diversity values within a plan.

\section{Spatial}

The spatial group has six pairs of variables, with moderate to strong relationships between most but not all variables across all plans. The only strong relationship is between the number of First Nations and 
reserve land extent $\left(r=0.93, r^{2}=0.86\right)$. Excluding outliers does not significantly change the strength of that relationship $\left(r=0.90 \mathrm{~m}, r^{2}=0.81\right)$, but does reveal another strong positive relationship between reserve extent and reserve proportion $\left(r=0.87, r^{2}=0.76\right)$.

Considering all plans, moderate strength relationships include the number of First Nations and both watershed extent $(r=0.63)$ and proportion of reserve land $(r=0.58)$, as well as reserve extent and proportion of reserve land $(r=0.59)$. Excluding outliers, the strength of the relationship between number of bands and watershed extent weakens $(r=0.42)$, number of First Nations and proportion of reserve land strengthens but stays moderate $(r=0.70)$, and reserve extent and proportion reserved becomes strong $(r=0.87)$.

\section{Combined}

With all plans considered, there are no strong relationships between content and spatial variables. Relationships of moderate strength are: number of First Nations with keyword occurrences $(r=0.65)$ and theme diversity $(r=0.55)$; and theme diversity and reserve extent $(r=0.53)$. Excluding outliers changes the relationships considerably. Three strong relationships appear between: number of First Nations with keyword occurrence $\left(r=0.91, r^{2}=0.83\right)$ and theme diversity $\left(r=0.87, r^{2}=0.75\right)$, and reserve extent and keyword occurrence $\left(r=0.93, r^{2}=0.86\right)$. As shown for each of those strong relationships, the independent variable explains most of the variation in the dependent variables.

Table 5. Matrix of Correlation Values for Content and Spatial Variables

\begin{tabular}{|c|c|c|c|c|c|c|}
\hline & $\begin{array}{l}\text { Keyword } \\
\text { occurrences }\end{array}$ & $\begin{array}{l}\text { Theme } \\
\text { diversity }\end{array}$ & $\begin{array}{l}\text { \# of First } \\
\text { Nations } \\
\text { with land }\end{array}$ & $\begin{array}{c}\text { Watershed } \\
\text { area } \\
(\mathrm{sq} . \mathrm{km})\end{array}$ & $\begin{array}{l}\text { Reserve land } \\
(\text { sq. km) }\end{array}$ & $\begin{array}{c}\% \text { Reserve } \\
\text { land }\end{array}$ \\
\hline $\begin{array}{l}\text { Keyword } \\
\text { occurrences }\end{array}$ & 1 & & & & & \\
\hline Theme diversity & 0.825 & 1 & & & & \\
\hline \# of bands with land & 0.652 & 0.553 & 1 & & & \\
\hline $\begin{array}{l}\text { Watershed area } \\
(\mathrm{sq} . \mathrm{km})\end{array}$ & 0.448 & 0.371 & 0.634 & 1 & & \\
\hline $\begin{array}{l}\text { Reserve area } \\
(\mathrm{sq} . \mathrm{km})\end{array}$ & 0.527 & 0.411 & 0.928 & 0.469 & 1 & \\
\hline \% Reserve land & 0.116 & 0.174 & 0.575 & -0.101 & 0.768 & 1 \\
\hline
\end{tabular}

Note. Values that exceed our threshold of moderate strength $(r>0.50)$ are emphasized in bold, and further discussed in the text. Shading is used to visually distinguish the content variables (top left), spatial variables (right), and combinations of content and spatial variables (lower left). 
Table 6. Matrix of Correlation Values for Content and Spatial Variables, Excluding Outliers

\begin{tabular}{rcccccc}
\hline & $\begin{array}{c}\text { Keyword } \\
\text { occurrences }\end{array}$ & $\begin{array}{c}\text { Theme } \\
\text { diversity }\end{array}$ & $\begin{array}{c}\text { \# of First } \\
\text { Nations } \\
\text { with land }\end{array}$ & $\begin{array}{c}\text { Watershed } \\
\text { area } \\
\text { (sq. km) }\end{array}$ & $\begin{array}{c}\text { Reserve } \\
\text { land } \\
\text { (sq. km) }\end{array}$ & $\begin{array}{c}\text { \% Reserve } \\
\text { land }\end{array}$ \\
\hline $\begin{array}{r}\text { Keyword } \\
\text { occurrences }\end{array}$ & 1 & & & & & \\
Theme diversity & $\mathbf{0 . 8 4 8}$ & 1 & & & \\
\# of bands w/ land & $\mathbf{0 . 9 0 9}$ & $\mathbf{0 . 8 6 8}$ & 1 & & \\
$\begin{array}{r}\text { Watershed area } \\
\text { (sq. km) }\end{array}$ & 0.357 & 0.401 & 0.423 & 1 & 1 \\
$\begin{array}{r}\text { Reserve land } \\
\text { (sq. km) }\end{array}$ & $\mathbf{0 . 9 2 5}$ & $\mathbf{0 . 7 3 0}$ & $\mathbf{0 . 8 9 9}$ & 0.179 & \\
\% Reserve land & $\mathbf{0 . 6 7 7}$ & $\mathbf{0 . 5 2 2}$ & $\mathbf{0 . 6 9 6}$ & -0.261 & 0.873 \\
\hline
\end{tabular}

Note. Values that exceed our threshold of strength $(r>0.50)$ are emphasized in bold, and further discussed in the text. Shading is used to visually distinguish the content variables (top left), spatial variables (right), and combinations of content and spatial variables (lower left).

\section{Analysis}

This analysis is exploratory in seeking to understand how Indigenous content of watershed plans relate to the four spatial variables discussed above. There are two assumptions with this analysis. First, if there is more total reserved land in one watershed than another, then those lands - and the First Nations for whom they are reserved - are more likely to be impacted by changes in surrounding land use or water management. If this is so, we expect to see more Indigenous issues, interests, and values documented in the plan with more reserve land. Second, the more individual First Nations with land in a watershed should increase the number and diversity of First Nations' issues, interests, and values documented in the plan. Even if there are similarities between First Nations in their values, interests, and concerns, we would still expect to see some diversity in the evidence of their inclusion and participation in the plans.

\section{Content}

With higher rates of keyword occurrences, we could expect to see a greater diversity of Indigenous interests and knowledge addressed and included in a plan, although there are still other factors at play. The influence of the outlier plans on $r$ and $r^{2}$ values for these variables also appears to be minor. It is possible that the relationship between these two variables is non-linear, at least with regard to the keywords used and themes developed in the content analysis. Further differentiation of themes into subcategories could be used to further identify potential drivers of variation between the plans in terms of Indigenous engagement. 


\section{Spatial}

There are strong relationships between the number of First Nations with land in a watershed and the extent of reserve lands, as well as between the extent and proportion of reserve land in the watersheds. Further statistical analysis could be used to tease out the nuances of these three variables to better understand how different configurations of land, title, and watershed extent influence Indigenous engagement, but there are other considerations that may not be statistically evident.

If the extent of reserve land is dependent on the number of First Nations with land in the catchment, understanding the nature of that relationship is complicated by the historic treaty process (Ray, Miller, \& Tough, 2000), and by ongoing TLE processes and acquisition of urban reserve land. Some reserve land parcels are very large, and some (urban) very small. And so, increasing the extent of reserved land in a watershed is not solely contingent on having additional First Nations with land in the watershed. Conversely, many First Nations may have land in a watershed, but if they are mostly urban parcels, the extent of reserved land will only increase fractionally.

We can imagine an upper bound to the number of First Nations that would have land in a watershed, in accordance with traditional territory for normative claims for inclusion and TLE or other settlement agreements. But we can also speculate that such a limit would not necessarily constrain increases in the proportion of additional land in a watershed that First Nations and their members are able to purchase, although the parcels may not be reclassified as reserve land.

\section{Combined}

Of most significance here is the effect of the outliers in our interpretation. Given their contribution to each dataset, removing outlier plans from the analysis leads to significant changes in some of the relationships within the spatial data (reserve extent and proportion reserved), and between spatial and content variables. For the combined relationships, removing outliers increases the strength of the relationship between the number of First Nations with land in a watershed with both keyword occurrences and theme diversity.

Considering all watershed plans, we conclude that the extent of reserve land within a watershed has the strongest relationship with keyword occurrences, and that the number of First Nations with land in a watershed has the strongest relationship with theme diversity. By excluding the outliers, we find that the number of First Nations with land has the strongest relationship with both keyword occurrences and theme diversity. In both cases, the number of First Nations with land has the strongest relationship with theme diversity, but for keyword frequency, extent is more strongly related than the number of First Nations.

Distribution of reserve land across watersheds and between First Nations is a consideration that is not fully captured in this analysis. Uneven distribution, combined with uneven participation, can significantly affect the amount and type of Indigenous content in a plan if First Nations with a greater proportion of the reserved lands (and thus a higher chance of being affected by water management) are not included in the planning process. 


\section{Limitations}

These findings are a preliminary description of relationships between the variables identified. We cannot extensively generalize or extrapolate beyond the dataset, since the number of bands with time and resources to participate in watershed planning will vary, along with their respective issues and interests. Though we do not consider it here, land use or cover within or near reserve land will likely also influence inclusion to some degree, as direct or proximate interests in water and land will likely vary by ecological and geographic context. Similarly, proximity of reserve lands to water features might influence participation, especially in the context of development activities impacting Indigenous rights or lands.

\section{Discussion}

Under the Saskatchewan watershed planning model (Saskatchewan Watershed Authority, 2003) watershed planning progressed rapidly, albeit unevenly, between 2006 and 2014 (11 watershed plans). The more populated, warmer, and drier southern part of the province-predominantly privately held agricultural land but also including some public pastures- has significantly more completed watershed plans compared to the north, which includes forestry and mining interests, as well as significant areas of Crown-owned lands. Most of the rivers also flow north, resulting in an emphasis on water allocation and drinking water protection. This framing may have an impact on Indigenous engagement by bracketing out other concerns that are deemed beyond the scope of the planning process.

The Saskatchewan watershed planning model (Saskatchewan Watershed Authority, 2003) notes that "social priority and watershed health ranking [will be used] to assist in focusing efforts on those watersheds most needing attention" (p. 10). How those criteria interact with Indigenous issues, given the fragmentation of jurisdiction and responsibility between the provinces, federal, and First Nation governments, needs further investigation.

Given that most of the plans $(n=9)$ were completed prior to the release of the 2012 planning policy, this study provides a baseline of Indigenous inclusion according to the 2003 planning model. The manifest and latent content analyses provide insight into the frequency of keywords and variety of thematic contexts in the plan documents (McLeod et al., 2015; Plummer et al., 2011; Wyatt et al., 2011). With the keywords counted and themes tallied, we sought some explanation for the variation across and within these planning documents. To do so, we considered the role of land use and property, and the concept of stakeholder participation, by way of a spatial analysis.

By spatializing our content analysis, we revealed the extent to which two factors might drive some of this variation: the percentage of reserve land in a watershed, and the number of First Nations with land in a watershed. Evidence of inclusion in watershed plans - as keyword occurrences and theme diversitydoes appear to increase in a positive relationship with the number of First Nations with land, and to a lesser degree the total extent of reserve lands in a watershed.

However, the three watershed plan outliers (in terms of keyword frequency and thematic diversity) challenged the spatial relationship found in the other plans, increasing the strength of some relationships while reducing others; further research is necessary to understand why. Interviews with planners, committee members, and community leaders may help to identify potential factors in the significant 
variation in documented evidence of Indigenous engagement across, and diversity of engagement within, plan documents (Montgomery et al., 2016; Morton et al., 2012). This will provide further insight into the barriers to and opportunities for Indigenous participation and inclusion in the planning process. Additionally, we need to consider the potential role of the Water Security Agency 25 Year Plan on future involvement of Indigenous Peoples in watershed planning. Only two plans (Lower Qu'Appelle in 2013 and Old Wives Lake in 2014) have been completed since the release of the 25 Year Plan in October of 2012.

Consultation under the Constitution Act (1867) Section 35 is not required for Indigenous engagement in the new planning model, but it is still identified as a goal within the 25 Year Plan, where guidance is given as to how the planning system should interface with Indigenous Peoples and governments. If we consider this as a policy document, if not a successor of the 2003 planning model, then future researchers should conduct a similar analysis for subsequent plans in order to assess the outcomes of and outputs from the 25 Year Plan's approach to Indigenous engagement.

Considering how Indigenous communities were historically placed and/or relocated by the dominion and federal governments, as well as the contemporary economic drivers of land acquisition, reserve land extent may not be the most appropriate criteria for inclusion in watershed planning (Nadasdy, 2002; Natcher, Davis, \& Hickey, 2005; Usher, Tough, \& Galois, 1992). Using the concepts of property and ownership to compare Indigenous engagement across watershed plans may at first appear problematic, since those concepts have been used to displace and dispossess Indigenous Peoples, foster settlement, and to exploit the land and environment. Traditional territory and historic use, as identified through traditional land use and occupancy studies or other community-based research formats, would provide a better basis than reserve land to ensure adequate recognition and inclusion of Indigenous interests in watershed planning. Even so, this research shows a relationship between property ownership by First Nations and inclusion in watershed planning, both procedurally as participation, and substantively as inclusion in implementation.

As an analysis of Indigenous participation, this study offers a glimpse of the dynamics of watershed governance, especially for Indigenous engagement. For a more holistic view, this type of analysis could be extended with a number of other approaches to research. These include an assessment of participation by other industry, government, civil, and private interests (Ferreyra \& Beard, 2007; Montgomery et al., 2016; Morton et al., 2012), as well as the consideration of other social and demographic dimensions of Indigenous and watershed communities (rural and urban, status and nonstatus, educational achievement, income; Basdeo \& Bharadwaj, 2013; Cairns, 2000; Lukasiewicz \& Baldwin, 2014; Reed \& McIlveen, 2006). Future research on committee membership, inclusion in implementation and discussion of rights would be fruitful to clarify the extent to which Indigenous Peoples are included in watershed planning and how their interests are balanced against others in terms of frequency, coverage, and type of interest. A gendered analysis would also provide insight into representation and voice of women - Indigenous and non-Indigenous - as well as other communities (urban), in provincial watershed planning (Anderson, 2010; Anderson, Clow, \& Haworth-Brockman, 2013; Lawless, Taylor, Marshall, Nickerson, \& Anderson, 2013; Zwarteveen, 2010). 


\section{Conclusion}

Through the Saskatchewan Watershed Authority and then the Water Security Agency, the Government of Saskatchewan embarked on an ambitious watershed planning program between 2006 and 2014. In total, 11 watershed plans were developed for the southern, more populated half of the province. This research set out to determine the degree to which Indigenous Peoples (as individual and community members of First Nation and Métis communities) have been engaged and included in those watershed plans. To do this, we conducted content analysis within each of the 11 plans looking for keywords that would indicate some degree of involvement, or interaction, between the plan or the planning process and Indigenous communities. Next, we identified themes that emerged from keyword context within the text of the plan. Last, we explored the extent and number of First Nations with reserve lands in a watershed, and the frequency and context of keywords in the plan documents.

The results of this research show that, on average, Indigenous engagement is limited and minimal in watershed planning in Saskatchewan, but three of the plans are an exception to this pattern. Arguably, the Indian reserve system was purposefully designed by the state to disconnect Indigenous Peoples from active livelihoods, cultural practices, and family kinship (Patrick, Grant, \& Bharadwaj, 2019). By extension, the reserve system has also served to exclude Indigenous Peoples from active participation in watershed planning by privileging land ownership over land use (Krueckeberg, 1995; Natcher, 2001). As a function of policy and protocol, the prior watershed planning process in Saskatchewan provided little space for inclusion of Indigenous voices, values, and perspectives. The current approach, under the 25 Year Plan, will need to be further analyzed as more plans are completed.

We view the absence of Indigenous inclusion and engagement in watershed planning as a missed opportunity on several fronts. First, while watershed planning requires participation of multiple partners, stakeholders and rights holders (Montgomery et al., 2016), there is a strong normative emphasis on the inclusion of Indigenous voices, knowledge, and interests in water governance more generally (Bradford et al., 2017). Second, water (and land) management to control for water quality and quantity within a watershed will be more efficient when coordinated between and among watershed groups, actors, and organizations, including First Nations, Métis, and Indigenous organizations (Noble, 2016; Udofia et al., 2016). Last, and perhaps most significant, watershed planning provides a pathway toward reconciliation (Castleden et al., 2017; Truth \& Reconciliation Commission of Canada, 2015; Zurba, 2014). The potential for trust and reciprocity between ENGOs, government, industry, and Indigenous communities remains largely unexplored under both of Saskatchewan's watershed planning models.

This research has shown that, while the amount and type of Indigenous content in watershed plans is related to the amount of reserve land and the number of First Nations with land in a watershed, these are not the only factors. Increasing Indigenous land holdings is no guarantee of future engagement, nor is it the sole explanation for past engagement. There are opportunities not only for greater participation and partnership with First Nations and Métis in Saskatchewan watershed planning, but also to further examine the relationships between physical factors and the amount and types of Indigenous content evident in watershed plans. Given the deterioration of many streams and water bodies across Canada, including cumulative impacts from past and present development, as well as future water scarcity and climate uncertainty, there is no better time than now for cross-cultural collaboration in watershed planning. 


\section{References}

Agriculture and Agri-Foods Canada. (2013). PFRA sub-basins of the AAFC Watersheds Project-2013 [Data file]. Retrieved from https://open.canada.ca/data/en/dataset/4f3c7d6d-e018-4a69-a6cf$\underline{\mathrm{a} 4 \mathrm{c} 327572 \mathrm{~b} 24}$

Anderson, K. (2010). Aboriginal women, water and health: Reflections from eleven First Nations, Inuit, and Métis grandmothers. Retrieved from http://pwhce.ca/pdf/womenAndWater.pdf

Anderson, K., Clow, B., \& Haworth-Brockman, M. (2013). Carriers of water: Aboriginal women's experiences, relationships, and reflections. Journal of Cleaner Production, 60, 11-17. doi: https://doi.org/10.1016/j.jclepro.2011.10.023

Arsenault, R., Diver, S., McGregor, D., Witham, A., \& Bourassa, C. (2018). Shifting the framework of Canadian water governance through Indigenous research methods: Acknowledging the past with an eye on the future. Water, 1O(1). doi: https://doi.org/10.3390/w10010049

Assiniboine River Watershed Advisory Committees. (2006). Assiniboine river watershed source water protection plan. Retrieved from https://www.wsask.ca/Water-Info/WatershedPlanning/Assiniboine-River-Watershed/

Baijius, W., \& Patrick, R. J. (2019). “We don't drink the water here”: The reproduction of undrinkable water for First Nations in Canada. Water, 11(5), 1079. doi: https://doi.org/10.3390/ $\underline{\mathrm{w} 11051079}$

Bartlett, R. H. (1988). Aboriginal water rights in Canada: A study of Aboriginal title to water and Indian water rights. Calgary, Canada: Canadian Institute of Resources Law.

Basdeo, M., \& Bharadwaj, L. (2013). Beyond physical: Social dimensions of the water crisis on Canada's First Nations and considerations for governance. Indigenous Policy Journal, 23(4). Retrieved from http://www.indigenouspolicy.org/index.php/ipj/article/view/142/130

Belanger, Y. D. (2010). Ways of knowing: An introduction to Native studies in Canada. Toronto, ON: Nelson Education.

Blomley, N. (2016). Land use, planning, and the "difficult character of property." Planning Theory \& Practice, 18(3), 351-364. doi: https://doi.org/10.1080/14649357.2016.1179336

Borrows, J. (2002). Recovering Canada: The resurgence of Indigenous law. ON: University of Toronto Press.

Borrows, J. (2005). Crown and Aboriginal occupations of land: A history \& comparison (Ipperwash Inquiry). Retrieved from https://www.attorneygeneral.jus.gov.on.ca/inquiries/ipperwash/ policy_part/research/pdf/History_of_Occupations_Borrows.pdf 
Bradford, L. E. A., Ovsenek, N., \& Bharadwaj, L. A. (2017). Indigenizing water governance in Canada. In S. Renzetti \& D. P. Dupont (Eds.), Water policy and governance in Canada (pp. 269-298). doi: https://doi.or/10.1007/978-3-319-42806-2_15

Cairns, A. (2000). Citizens plus: Aboriginal Peoples and the Canadian state. Vancouver, Canada: UBC Press.

Carr, G., Blöschl, G., \& Loucks, D. P. (2012). Evaluating participation in water resource management: A review. Water Resources Research, 48(11). doi: https://doi.org/10.1029/2011WR011662

Carrot River Valley Watershed Association. (2012). Carrot River watershed source water protection plan. Retrieved from https://www.wsask.ca/Water-Info/Watershed-Planning/Carrot-RiverWatershed/

Castleden, H., Hart, C., Cunsolo, A., Harper, S., \& Martin, D. (2017). Reconciliation and relationality in water research and management in Canada: Implementing Indigenous ontologies, epistemologies, and methodologies. In S. Renzetti \& D. P. Dupont (Eds.), Water policy and governance in Canada (pp. 69-95). doi: https://doi.org/10.1007/978-3-319-42806-2_5

Clogg, J., Askew, H., Kung, E., \& Smith, G. (2016). Indigenous legal traditions and the future of environmental governance in Canada. Journal Environmental Law Practice, 29, 227-256.

Constitution Act, 186730 \& 31 Victoria, c. 3 (U.K.)

Cuvelier, C., \& Greenfield, C. (2017). The integrated watershed management planning experience in Manitoba: The local conservation district perspective. International Journal of Water Resources Development, 33(3), 426-440. doi: https://doi.org/10.1080/07900627.2016.1217504

Ferreyra, C., \& Beard, P. (2007). Participatory evaluation of collaborative and integrated water management: Insights from the field. Journal Environmental PlanningManagement, 50(2), 271296. doi: https://doi.org/10.1080/09640560601156532

Ferreyra, C., de Loë, R. C., \& Kreutzwiser, R. D. (2008). Imagined communities, contested watersheds: Challenges to integrated water resources management in agricultural areas. Journal Rural Studies, 24(3), 304-321. doi: http://doi.org/10.1016/j.jrurstud.2007.11.001

Fortier, J.-F., Wyatt, S., Natcher, D. C., Smith, M. A., \& Hébert, M. (2013). An inventory of collaborative arrangements between Aboriginal Peoples and the Canadian forest sector: Linking policies to diversification in forms of engagement. Journal Environmental Management, 119, 47-55. doi: https://doi.org/10.1016/j.jenvman.2013.01.005

Government of Canada. (1982). Constitution Acts, 1867 to 1982. Retrieved from https://lawslois.justice.gc.ca/eng/const/ 
Hanna, P., Langdon, E. J., \& Vanclay, F. (2016). Indigenous rights, performativity and protest. Land Use Policy, 50, 490-506. doi: https://doi.org/10.1016/j.landusepol.2015.06.034

Hodge, G., Hall, H. M., \& Robinson, I. M. (2016). Planning Canadian regions ( $2^{\text {nd }}$ ed.). Vancouver, Canada: UBC Press.

Howitt, R., \& Suchet-Pearson, S. (2006). Rethinking the building blocks: Ontological pluralism and the idea of 'management.' Geografiska Annaler, Series B Human Geography, 88(3), 323-335. doi: https://doi.org/10.1111/j.1468-0459.2006.00225.x

Hurlbert, M., \& Andrews, E. (2018). Deliberative democracy in Canadian watershed governance. Water Alternatives, 11(1), 163.

Indian Act (R.S.C., 1985, c. I-5). Retrieved from https://laws-lois.justice.gc.ca/eng/acts/I-5/

Information Services Corporation of Saskatchewan. (2015). Sask Admin 2015 Indian Reserves. Retrieved from https://www.isc.ca/

Irvine, J. T. (2002). Water law in Canada: Federal and provincial jurisdiction. Proceedings. Saskatoon, Canada: Partners FOR the Saskatchewan River Basin and others.

Krueckeberg, D. (1995). The difficult character of property: To whom do things belong? Journal of the American Planning Association, 61(3), 301-309. doi: https://doi.org/10.1080/ $\underline{01944369508975644}$

Lawless, J.-A., Taylor, D., Marshall, R., Nickerson, E., \& Anderson, K. (2013). Women, diverse identities and Indigenous water and wastewater reponsibilities. Canadian Woman Studies, 30(2/3), 81.

Lebel, P. M., \& Reed, M. G. (2010). The capacity of Montreal Lake, Saskatchewan to provide safe drinking water: Applying a framework for analysis. Canadian Water Resources Journal, 35(3), 317-338. doi: https://doi.org/10.4296/cwrj3503317

Lower Qu'Appelle Watershed Stewards. (2013). Lower Qu'Appelle River watershed plan. Retrieved from https://www.wsask.ca/Water-Info/Watershed-Planning/Lower-QuAppelle-RiverWatershed/

Lower Souris River Watershed Advisory Committees. (2006). Lower Souris River watershed protection plan. Retrieved from https://www.wsask.ca/Water-Info/Watershed-Planning/Lower-SourisRiver-Watershed/

Lukasiewicz, A., \& Baldwin, C. (2014). Voice, power, and history: Ensuring social justice for all stakeholders in water decision-making. Local Environment, 22, 1042-1060. doi: https://doi.org/10.1080/13549839.2014.942261 
Maclean, K., Robinson, C. J., \& Natcher, D. C. (2015). Consensus building or constructive conflict? Aboriginal discursive strategies to enhance participation in natural resource management in Australia and Canada. Society \& Natural Resources, 28(2), 197-211. doi: https://doi.org/ $\underline{10.1080 / 08941920.2014 .928396}$

McGregor, D. (2014). Traditional knowledge and water governance: The ethic of responsibility. AlterNative: An International Journal Indigenous Peoples, 10(5). doi: https://doi.org/ $\underline{10.1177 / 117718011401000505}$

McLeod, F., Viswanathan, L., Whitelaw, G. S., Macbeth, J., King, C., McCarthy, D. D., \& Alexiuk, E. (2015). Finding common ground: A critical review of land use and resource management Policies in Ontario, Canada and their intersection with First Nations. The International Indigenous Policy Journal, 6(1). doi: https://doi.org/10.18584/iipj.2015.6.1.3

Montgomery, J., Xu, W., Bjornlund, H., \& Edwards, J. (2016). A table for five: Stakeholder perceptions of water governance in Alberta. Agricultural Water Management, 174, 11-21. doi: https://doi.org/10.1016/j.agwat.2016.04.013

Moose Jaw River Watershed Advisory Committees. (2006). Moose Jaw River watershed source water protection plan. Retrieved from https://www.wsask.ca/Water-Info/WatershedPlanning/Moose-Jaw-River-Watershed/

Morrison, A., Bradford, L., \& Bharadwaj, L. (2015). Quantifiable progress of the First Nations water management strategy, 2001-2013: Ready for regulation? Canadian Water Resources Journal/Revue canadienne des ressources hydriques, 4O(4), 1-21. doi: https://doi.org/ $\underline{10.1080 / 07011784.2015 .1080124}$

Morton, C., Gunton, T. I., \& Day, J. C. (2012). Engaging Aboriginal populations in collaborative planning: An evaluation of a two-tiered collaborative planning model for land and resource management. Journal Environmental Planning Management, 55(4), 507-523. doi: https://doi.org/10.1080/09640568.2011.613592

Nadasdy, P. (2002). "Property" and Aboriginal land claims in the Canadian Subarctic: Some theoretical considerations. American Anthropologist, 104(1), 247-261. doi: https://doi.org/ $\underline{10.2307 / 683774}$

Nadasdy, P. (2004). Hunters and bureaucrats: Power, knowledge, and Aboriginal-state relations in the southwest Yukon. Vancouver, Canada: UBC Press.

Natcher, D. C. (2001). Land use research and the duty to consult: A misrepresentation of the Aboriginal landscape. Land Use Policy, 18(2), 113-122. doi: https://doi.org/10.1016/S0264-8377(01)00011$\underline{4}$ 
Natcher, D. C., Davis, S., \& Hickey, C. G. (2005). Co-management: Managing relationships, not resources. Human Organization, 64(3), 240-250. doi: https://doi.org/10.17730/ humo.64.3.23yfnkrl2ylapjxw

Noble, B. (2016). Learning to listen: Snapshots of Aboriginal participation in environmental assessment. Retrieved from http://www.macdonaldlaurier.ca/files/pdf/Noble StewardshipCaseStudies_F_web.pdf

North Saskatchewan River Basin Council. (2008). North Saskatchewan River watershed source water protection plan. Retrieved from https://www.wsask.ca/Water-Info/WatershedPlanning/North-Saskatchewan-River-Watershed/

Old Wives Watershed Association. (2014). Old Wives Lake watershed plan. Retrieved from https://www.wsask.ca/Water-Info/Watershed-Planning/Old-Wives-Lake-Watershed/

Patrick, R. J. (2014). Source water protection planning: A role for planners. Alberta Professional Planners Institute Journal, 13, 12-16.

Patrick, R. J., Grant, K., \& Bharadwaj, L. (2019). Reclaiming Indigenous planning as a pathway to local water security. Water, 11(5), 936. doi: https://doi.org/10.3390/w11050936

Patrick, R. J., Machial, L., Quinney, K., \& Quinney, L. (2017). Lessons learned through communityengaged planning. The International Indigenous Policy Journal, $8(2)$, 7. doi: https://doi.org/ 10.18584/iipj.2017.8.2.7

Phare, M.-A. S. (2009). Denying the source: The crisis of First Nations water rights. Vancouver, Canada: Rocky Mountain Books Ltd.

Plummer, R., Grosbois, D. de, de Loë, R. C., \& Velaniškis, J. (2011). Probing the integration of land use and watershed planning in a shifting governance regime. Water Resources Research, 47(9), 113. doi: https:/doi.org/10.1029/2010WR010213

Porten, S. von der, Loë, R. C. de, \& Plummer, R. (2015). Collaborative environmental governance and Indigenous Peoples: Recommendations for practice. Environmental Practice, 17(02), 134-144. doi: https://doi.org/10.1017/S146604661500006X

Ray, A. J., Miller, J., \& Tough, F. (2000). Bounty and benevolence: A history of Saskatchewan treaties. Montreal \& Kingston, Canada: McGill-Queens University Press.

Reed, M. G., \& McIlveen, K. (2006). Toward a pluralistic civic science? Assessing community forestry. Society \& Natural Resources, 19(7), 591-607. doi: https://doi.org/10.1080/ $\underline{08941920600742344}$ 
Rizvi, Z., Adamowski, J., \& Patrick, R. J. (2013). First Nation capacity in Québec to practise integrated water resources management. International Journal Water, 7(3), 161-190. doi: https://doi.org/ $\underline{10.1504 / \mathrm{IJW} .2013 .054859}$

Samuel, M., \& Okey, L. (2015). The relevance and significance of correlation in social science research. International Journal Sociology Anthropology Research, 1(3), 22-28.

Saskatchewan Watershed Authority. (2003). Protecting our water: A watershed and aquifer planning model for Saskatchewan. Regina, Canada: Author.

Saskatchewan Watershed Authority. (2013). Saskatchewan watersheds. Retrieved from http://datalib.usask.ca/gis/Data/WSAwatershedSK/newwatershedssk.zip

Simms, R., Harris, L., Joe, N., \& Bakker, K. (2016). Navigating the tensions in collaborative watershed governance: Water governance and Indigenous communities in British Columbia, Canada. Geoforum, 73, 6-16. doi: https://doi.org/10.1016/j.geoforum.2016.04.005

South Saskatchewan River Watershed Stewards Inc. (2007). South Saskatchewan River watershed source water protection plan. Retrieved from https://www.wsask.ca/Water-Info/WatershedPlanning/South-Saskatchewan-River-Watershed/

Stewart, J., \& Bennett, M. (2017). Integrated watershed management in the Bow River Basin, Alberta: Experiences, challenges, and lessons learned. International Journal of Water Resources Development, 33(3), 458-472. doi: https://doi.org/10.1080/07900627.2016.1238345

Swift Current Creek Watershed Stewards, \& Swift Current Creek Watershed Advisory Committee. (2009). Swift Current Creek watershed protection plan. Retrieved from https://www.wsask.ca/ Water-Info/Watershed-Planning/Swift-Current-Creek-Watershed/

Truth \& Reconciliation Commission of Canada. (2015). Calls to action. doi: https://doi.org/ $\underline{10.5663 / a p s . v 5 i 1.25647}$

Udofia, A., Noble, B., \& Poelzer, G. (2016). Meaningful and efficient? Enduring challenges to Aboriginal participation in environmental assessment. Environmental Impact Assessment Review, 65, 164174. doi: https://doi.org/10.1016/j.eiar.2016.04.008

Upper Qu'Appelle River \& Wascana Creek Watersheds Advisory Committees. (2008). Getting to the source: Upper Qu'Appelle River and Wascana Creek watersheds source water protection plan. Retrieved from https://www.wsask.ca/Water-Info/Watershed-Planning/Upper-QuAppelleRiver-and-Wascana-Creek-Watersheds/

Upper Souris Watershed Association. (2010). Upper Souris River watershed source water protection plan. Retrieved from https://www.wsask.ca/Water-Info/Watershed-Planning/Upper-SourisRiver-Watershed/ 
Usher, P. J., Tough, F. J., \& Galois, R. M. (1992). Reclaiming the land: Aboriginal title, treaty rights and land claims in Canada. Applied Geography, 12(2), 109-132. doi: https://doi.org/10.1016/ $\underline{0143-6228(92) 90002-5}$

Valverde, M. (2005). Taking land use seriously: Toward an ontology of municipal law. Law Text Culture, 9, 34.

Walters, D., Spence, N., Kuikman, K., \& Singh, B. (2012). Multi-barrier protection of drinking water systems in Ontario: A comparison of First Nation and non-First Nation communities. The International Indigenous Policy Journal, 3(3). doi: https://doi.org/10.18584/ iipj.2012.3.3.8

Wanvik, T. I., \& Caine, K. (2017). Understanding Indigenous strategic pragmatism: Métis engagement with extractive industry developments in the Canadian North. Extractive Industries Society International Journal, 4(3), 595-605. doi: https://doi.org/10.1016/j.exis.2017.04.002

Water Security Agency. (2012). 25 year water security plan. Retrieved from the Government of Saskatchewan website: https://www.wsask.ca/About-WSA/25-Year-Water-Security-Plan/

Wolfe, P. (2006). Settler colonialism and the elimination of the Native. Journal Genocide Research, $8(4), 387-409$. doi: https://doi.org/10.1080/14623520601056240

Wyatt, S., Merrill, S., \& Natcher, D. (2011). Ecosystem management and forestry planning in Labrador: How does Aboriginal involvement affect management plans? Canadian Journal Forest Research, 41(11), 2247-2258. doi: https://doi.org/10.1139/x11-126

Zurba, M. (2014). Leveling the playing field: Fostering collaborative governance towards on-going reconciliation. Environmental Policy Governance, 24(2), 134-146. doi: $\underline{\text { https://doi.org/10.1002/eet.1631 }}$

Zwarteveen, M. (2010). A masculine water world: The politics of gender and identity in irrigation expert thinking. In R. Boelens, D. Getches, \& A. Guevara-Gil (Eds.), Out of the mainstream: Water rights, politics and identity (pp. 75-98). London, UK: Earthscan. 